\title{
STUDY OF THE PROPERTIES OF PLASMA DEPOSITED LAYERS OF NICKEL-CHROME-ALUMINIUM-YTTRIUM COATINGS RESISTANT TO OXIDATION AND HOT CORROSION
}

\author{
Mrdak R. Mihailo, IMTEL institute od Microwave Techniques \\ and Electronics, Belgrade
}

FIELD: Chemical Technology

DOI: 10.2298/vojtehg1202182M

ARTICLE TYPE: Original Scientific Paper

\section{Summary:}

The aim of this study was to examine the properties of Ni22Cr10Al1Y layers in order to obtain optimal structural - mechanical properties with the optimization of depositing parameters. Powder was deposited by the atmospheric plasma spray (APS) process with the current intensity of 600,700 and $800 \mathrm{~A}$, with a corresponding plasma gun power supply of $22 \mathrm{KW}, 34 \mathrm{KW}$ and $28 \mathrm{KW}$. The evaluation of the Ni22Cr10Al1Y coating layers was made on the basis of their microhardness, tensile strength and microstructure performance. The best performance was obtained in the layers deposited with 800A and the 34KW plasma gun power supply. The coating with the best characteristics was tested to oxidation in the furnace for heat treatment without a protective atmosphere at $1100^{\circ} \mathrm{C}$ for one hour. The examination of the morphology of Ni22Cr10Al1Y powder particles was carried out on the SEM (Scanning Electron Microscope) as well as the EDS analysis of the best layers. The microstructure of the deposited coating layers was examined with a light microscope. The microstructure analysis was performed according to the TURBOMECA standard. The mechanical properties of layers were evaluated by the method HVO.3 for microhardness and by tensile testing for bond strength. The research has shown that plasma gun power supply significantly affects the mechanical properties and microstructure of coatings that are of crucial importance for the protection of components exposed to high temperature oxidation and hot corrosion.

Key words: atmospheric plasma spray (APS), microstructure, interface, microhardness, bond strength, oxidation, hot corrosion.

\section{Introduction}

MeCralY type alloys ( $\mathrm{Me}=\mathrm{Ni}$, Co and $/$ or $\mathrm{Fe}$ ) are most often Iused for protecting the parts of jet engines from the influence of high temperatures, especially from the influence of oxidation and hot

" Acknowledgement: The author is thankful for the financial support from the Ministry of Education and Science of the Republic of Serbia (national projects OI 174004, TR 34016).

miki@insimtel.com 
corrosion. Selection and composition of materials are largely determined by optimizing the relations of physical - chemical properties of applied materials and substrates, operating temperature and a deposition method [1]. For NiCrAlY alloys, yttrium is usually added in certain quantities. Yttrium addition is essential, because it significantly increases the adhesion of $\mathrm{Al}_{2} \mathrm{O}_{3}$ and $\mathrm{Cr}_{2} \mathrm{O}_{3}$ oxides formed in the base coating thus preventing cracking and separation of the protective surface oxide layer due to the effects of thermal fatigue [2]. This prevents and minimizes the further development of high-temperature corrosion. It is especially important to ensure a uniform oxide distribution in metal-based coatings, in order to use fully the potential of these types of protective coatings. The idea to extend the life span of coatings regarding oxidation led to the development of Ni22Cr10Al1Y coatings. Coatings are commonly used in aerospace industry on the parts such as blades and other parts of gas turbines to protect them from high-temperature hot corrosion and oxidation up to $1100^{\circ} \mathrm{C}$ [3]. Selecting a right MeCrAlY coating depends on the operating conditions of the coating and the substrate to which it is applied. A complex interaction between the working environment, the coating and the substrate makes coating design and selection difficult. Generally, it is necessary to find a compromise between the required mechanical strength, resistance to hot corrosion, oxidation and adhesion. Years of experience in modeling the behavior of coating layers, together with improved techniques of deposit, led to the development of multicomponent coatings. The parameters of depositing have a very important influence on the quality of coating layers. For atmospheric plasma spray (APS) technique, one of the important parameters is the current intensity which affects: the degree of plasma gas ionization, the plasma temperature, the temperature of melting powder particles, their rate during depositing and their sagging on the substrate.

The main chemical element of NiCrAlY coatings, designed to protect against high temperature oxidation and hot corrosion should be compatible with the substrate material to reduce the diffusion, and reduce the chemical activity of Al. Aluminum is an element that protects the coating of the $\mathrm{Ni}$ alloy from oxidation at $1200^{\circ} \mathrm{C}$ by forming the phase $\alpha-\mathrm{Al}_{2} \mathrm{O}_{3} \mathrm{Y}^{\prime}-\mathrm{Ni}_{3} \mathrm{Al}$ and $\mathrm{Y}-\mathrm{Ni} / \mathrm{Y}^{\prime}-\mathrm{Ni}_{3} \mathrm{Al}$, basically an Ni alloy. The phase $\alpha-\mathrm{Al}_{2} \mathrm{O}_{3}$ in the basis of NiCrAlY alloy improves the oxidation resistance. The oxide phase $\alpha-\mathrm{Al}_{2} \mathrm{O}_{3}$ hinders the diffusion of $\mathrm{Ni}$ and $\mathrm{Cr}$ from inner layers to the surface of the coating and thus slows the growth of oxides $\mathrm{Cr}_{2} \mathrm{O}_{3}$ and $\mathrm{NiCr}_{2} \mathrm{O}_{4}$, which is attributed to a low diffusion coefficient of $\mathrm{Ni}$ and $\mathrm{Cr}$ along the grain boundaries of $\alpha-\mathrm{Al}_{2} \mathrm{O}_{3}$. 
The $\mathrm{Al}$ diffusion coefficient along the $\alpha-\mathrm{Al}_{2} \mathrm{O}_{3}$ grain boundaries is higher than $\mathrm{Ni}$ and $\mathrm{Cr}\left(\mathrm{Al}: 2.8 \times 10^{-4} \mathrm{~m}^{2} / \mathrm{s}, \mathrm{Cr}: 6.9 \times 10^{-11} \mathrm{~m}^{2} / \mathrm{s}, \mathrm{Ni}: 2.53\right.$ $\times 10^{-10} \mathrm{~m}^{2} / \mathrm{s}$ ) [4]. Chromium is used in coatings based on Ni due to its resistance to hot corrosion and oxidation up to $900^{\circ} \mathrm{C}$. Increasing the $\mathrm{Cr}$ content in the NiCrAlY alloy reduces the critical level of Al needed to form a continuous protective oxide $\alpha-\mathrm{Al}_{2} \mathrm{O}_{3}$. Yttrium improves the adhesion of oxides $\alpha-\mathrm{Al}_{2} \mathrm{O}_{3}$ and $\mathrm{Cr}_{2} \mathrm{O}_{3}$ and reduces the degree of chromium oxidation. In order to form continuous protective layers of oxides of $\alpha$ $\mathrm{Al}_{2} \mathrm{O}_{3}$ and $\mathrm{Cr}_{2} \mathrm{O}_{3}$ types on the coating surface and to prevent the formation of $\mathrm{NiO}$ oxides during exploitation, the lower concentration of $\mathrm{Cr}$ in the coating should be about $20 \%$ and Al content should be at least $5 \%$. Depending on the purpose of NiCrAlY coatings, the content of $\mathrm{Cr}$ and $\mathrm{Al}$ in the alloy changes. For optimal protection of substrates from hot corrosion and high temperature oxidation of the coating, MeCrAlY coatings contain 18-30 wt $\% \mathrm{Cr}$ and 5-14 wt\% Al [5,6,7-10]. The $\alpha-\mathrm{Al}_{2} \mathrm{O}_{3}$ oxide that forms in the coating is the thermodynamically stable phase that grows very slowly when compared to other types of oxides. Besides the presence of $\mathrm{Ni}, \mathrm{Cr}$ and $\mathrm{Al}$ oxides, there is also a spinel phase $\mathrm{NiCr}_{2} \mathrm{O}_{4}$ which also increases the oxidation resistance $[11,12,13]$. Chatterjee et al. [14] explained that the spinel phase provides better protection against oxidation due to the fact that spinels of mixed oxides of the general composition $\mathrm{AB}_{2} \mathrm{O}_{4}$ ( $\mathrm{A}$ and $\mathrm{B}$ are the two metal components) have much lower diffusion coefficients of cations and anions than the starting oxides of $\mathrm{NiO}$ and $\mathrm{Cr}_{2} \mathrm{O}_{3}$ [14].

According to the dual diagram $\mathrm{Ni}-\mathrm{Cr}$, in the structure of the coating there is present a solid solution $\mathrm{Y}-\mathrm{Ni}$ in which the substitution is $\mathrm{Cr}$ $[15,16]$. In order to obtain a solid solution of $\mathrm{Cr}$ in $\mathrm{Ni}$, the $\mathrm{Cr}$ content in the alloy should be in the range of 0 to $47 \mathrm{wt} \% \mathrm{Cr}$. In the structure of the coating there is the phase $\mathrm{Y}^{\prime}-\mathrm{Ni}_{3} \mathrm{Al}$ which is built by the binary system $\mathrm{Ni}$ Al with the Ni content over 42 wt.\% and with 3.5 to 14 wt.\% of Al $[15,16]$. In NiCrAY alloys with 10 wt $\%$ of $\mathrm{Al}$, a phase of $\mathrm{Al}_{7} \mathrm{Cr}\left(\mathrm{Al}_{13} \mathrm{Cr}_{2}\right)$ type cannot be obtained with the dual diagram Al - Cr $[15,16]$.

Generally, MeNiCrY powder is well deposited by the atmospheric plasma spray system and coatings have good adhesion to basic materials. The structure of the plasma spray coating deposited state presents two very important phases based on $\mathrm{Ni}\left(\mathrm{Y}-\mathrm{Ni}, \mathrm{Y}^{\prime}-\mathrm{Ni}_{3} \mathrm{Al}\right)$ and $\alpha-\mathrm{Al}_{2} \mathrm{O}_{3}$ oxide. The internal structure of the coating is a heterogeneous mixture of a metal base with non-melted powder particles, precipitates, micropores and oxides of nickel $\mathrm{NiO}$ and $\mathrm{Cr}_{2} \mathrm{O}_{3}$ and $\mathrm{NiCr}_{2} \mathrm{O}_{3}$. Exposing the coating to high temperatures leads to the oxidation of Al which forms an oxide of $\alpha-\mathrm{Al}_{2} \mathrm{O}_{3}$ type. This oxide is created on the coating surface 
due to high-speed Al diffusion. Only a small amount of $\mathrm{Al}$ remains in the regions rich in $\mathrm{Ni}, \mathrm{Cr}$ [17]. At a temperature of $1200^{\circ} \mathrm{C}$, $\mathrm{NiO}$ destabilizes in the coating and reacts with $\mathrm{Cr}_{2} \mathrm{O}_{3}$ forming a thin layer of an $\mathrm{NiCr}_{2} \mathrm{O}_{4}$ spinel phase which is thermodynamically more stable than $\mathrm{NiO}$ and $\mathrm{Cr}_{2} \mathrm{O}_{3}$ oxides $[18,19,20]$. A temperature of $1200^{\circ} \mathrm{C}$ in NiCrAlY coatings results in layers of mixed oxides of gray color. This gray area contains mixed oxides of $\mathrm{Al}_{2} \mathrm{O}_{3}, \mathrm{Cr}_{2} \mathrm{O}_{3}$ types and the spinel $(\mathrm{Ni}, \mathrm{Cr}){ }_{2} \mathrm{O}_{4},(\mathrm{Cr}, \mathrm{Al})$ ${ }_{2} \mathrm{O}_{4}[21]$.

Today, MeCrAlY coatings have been produced with different depositing processes. One of the standard processes for depositing is a plasma spray procedure. It is widely used owing to its smaller restriction in size and shape as well as to lower costs. In this paper, we presented the results of the experimental research into the effect of atmospheric plasma spray parameters on the mechanical properties and microstructure of layers of Ni22Cr10Al1Y coatings. The main objective was to homologate coatings and to apply them to the conduction garland of the gas turbine of the ASTAZOU III B turbo-jet engine. Three groups were done with samples of three different plasma gun power supplies $(22 \mathrm{KW}, 34 \mathrm{KW}$ and $28 \mathrm{KW})$, with the current intensity values of 600,700 and $800 \mathrm{~A}$. The coating with the best characteristics was tested in the oxidation furnace for a heat treatment without protective atmosphere at $1100^{\circ} \mathrm{C}$ for one hour. We analyzed and studied the microstructure and mechanical characteristics of selected coating layers in order to chose the highest quality coating and to homologate plasma spray parameters.

\section{Materials and details of the experiment}

The material substrate is made of stainless steel $\mathrm{X} 15 \mathrm{Cr} 13$ (EN 1.4024). The material is used in a thermally untreated state. For the production of coatings resistant to high-temperature oxidation and hot corrosion we used the AMDRY 962 powder of the company Sulzer Metco. This NiCrAlY powder is an alloy of nickel with 20 wt $\% \mathrm{Cr}, 10$ $w t \% A l$ and $1 \mathrm{wt} \% \mathrm{Y}$ with the range of grain size of powder particles from 53 microns to 106 microns. The powder of the Ni22Cr10Al1Y alloy applies and bind well to $\mathrm{Ni}$-and Fe-based substrates. It is produced by a vacuum melting technique and liquid melt atomization with inert gas. The technological process of making powder allows obtaining homogeneous spherical particles of powder. Fig. 1shows the SEM microphotography showing spherical powder particles of Ni22Cr10Al1Y. 


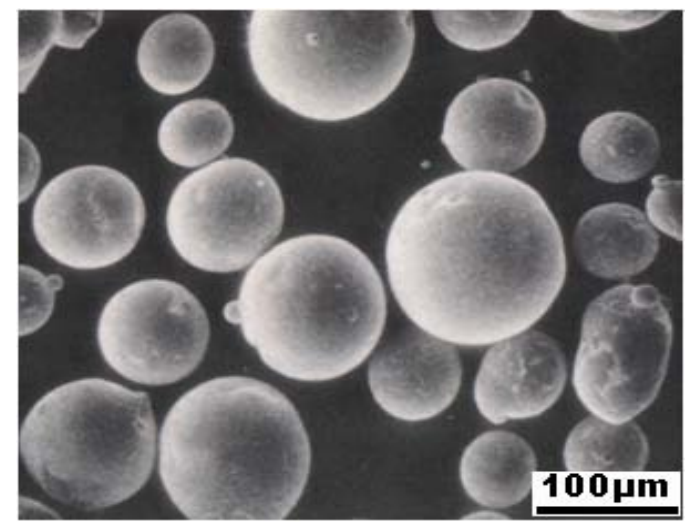

Figure 1 - (SEM) Scanning electron micrograph of powder particles of Ni22Cr10Al1Y Slika 1 - (SEM) Skening elektronska mikrografija čestica praha Ni22Cr10Al1Y

The atmospheric plasma spray (APS) was used in the experiment for the deposition of powder. For this purpose, we used a mini gun plasma spray gun of the Plasmadyne company, comprising: cathode type K: $1083-129$ A, anode type A : 2084 - F45 and of gas injector type Gl : 2084 B - 103. Argon gas was used in the combination with helium and electrical current from to 600.700 and $800 \mathrm{~A}$ with the power supply of the plasma gun of $22 \mathrm{KW}, 28 \mathrm{KW}$ and $34 \mathrm{KW}$. The detailed values of the spray parameters are shown in Table 1. Before the deposition process, the surface of the substrate steel is roughened with white corundum $\left(\mathrm{Al}_{2} \mathrm{O}_{3}\right)$ using a particle size of 0.7 to $1.5 \mathrm{~mm}$. Coatings are deposited with a thickness of 0.1 to $0.15 \mathrm{~mm}$. The coating with the best characteristics was tested to oxidation in a furnace for heat treatment without a protective atmosphere at $1100^{\circ} \mathrm{C}$ for one hour.

Table 1

Plasma spray parameters

Tabela 1

Plazma sprej parametri

\begin{tabular}{|c|c|}
\hline Deposition parameters & $\begin{array}{c}\text { Values for samples } \\
\text { A / B / C }\end{array}$ \\
\hline Electric current $(\mathrm{A})$ & $600 / 700 / 800$ \\
\hline Arc voltage $(\mathrm{V})$ & $36 / 40 / 42$ \\
\hline Primary plasma gas Ar (I/min ) & 50 \\
\hline Secondary plasma gas He (I/min) & 22 \\
\hline Wearing a powder gas Ar (I/min ) & 9 \\
\hline Flow of powder $(\mathrm{g} / \mathrm{min})$ & 50 \\
\hline Distance of the substrate $(\mathrm{mm})$ & 65 \\
\hline
\end{tabular}


The mechanical and microstructural characterizations of the obtained coatings were carried out according to the TURBOMECA standard [14]. For the measurement of hardness and metallographic tests, we used rectangular samples of $70 \times 20 \times 1.5 \mathrm{~mm}$, while the tensile strength was tested on cylindrical samples of $\varnothing 25 \times 50 \mathrm{~mm}$. The microstructural analysis of the coatings was made with the light microscope, while the SEM (Scanning Electron Microscope) was used for the morphology and EDS analysis of powder coatings tested for oxidation at $1100^{\circ} \mathrm{C}$ for one hour.

Microhardness measurements were made using a Vickers diamond pyramid indenter and $300 \mathrm{~g}$ load $\left(\mathrm{HV}_{0.3}\right)$. The measurement was carried out in the direction along the lamellae, in the middle and at the ends of the sample. Three readings were conducted at three points and the results were averaged.

Tensile tests were carried out at room temperature in hydraulic equipment with a rate of $10 \mathrm{~mm} / \mathrm{min}$ for all tests. The strength was calculated by dividing the breaking load by the sample cross-section. The geometry of the samples was in accordance with ASTM C633 standards. Pairs of two samples were used, but the coatings were deposited on only one of them. Samples were glued and kept under pressure in a furnace at a temperature of $180^{\circ} \mathrm{C}$ for 2 hours. For each group of samples three tests were done and the results were averaged.

\section{Results and Discussion}

The obtained values of microhardness and bond strength for Ni22Cr10Al1Y deposited coatings, depending on the spray parameters used, are shown in Figs. 2 and 3. For all the deposited coatings, we obtained microhardness values above the required value of $200 \mathrm{HV}_{0.3}[22,23,24]$. Electrical current values, directly related to the plasma gun power supply, significantly influenced the values of microhardness and the values of the layer bond strength. The highest values of microhardness of $342 \mathrm{HV}_{0.3}$ was found in the layers deposited on the sample $C$ with the highest current intensity of 800A. The higher electrical current affected the higher melting and increased the rate of powder melting. This resulted in better and denser packing of particles followed by a small portion of lamellar pores and oxides. The lowest value of microhardness of $220 \mathrm{HV}_{0.3}$ layers was deposited on the sample $A$ and was deposited with a current intensity of 600A. The layers with the highest microhardness had the smallest share of pores. These values were confirmed for all three groups of samples by analyzing the microstructure of coatings on a light microscope. The microhardness values were in line with the share of pores in the layers of deposited coatings. Differences in hardness of the layers should be attributed to oxide share, 
pores and the basis-oxide share ratio. Besides the difference in the proportion of oxide phases, microstructures may vary in dispersion of oxides, which is primarily determined by the degree of oxidation and cooling rate. The microhardness values were within the expected limits.

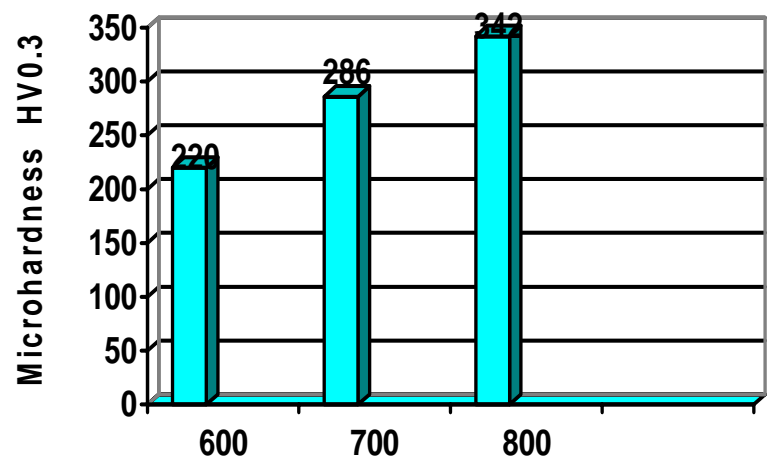

Electric carrent A

Figure 2 - Microhardness of Ni22Cr10Al1Y layers Slika 2 - Mikrotvrdoća Ni22Cr10Al1Yslojeva

The comparison of the values of coating bond strength obtained by tensile testing showed that for all three groups of samples the obtained values were higher than $35 \mathrm{MPa}$, as required by the appropriate standard [22]. The lower value of the tensile bond strength of 36MP occurred in a coating on the sample $A$ as a consequence of lower current intensity, which resulted in a lower degree of fusion of powder particles compared to the other two layers deposited with a higher current intensity value. The best bond strength of 54MPa was found in the layers deposited with the highest amperage in the sample $\mathrm{C}$. These layers had the lowest proportion of pores and coarse oxides.

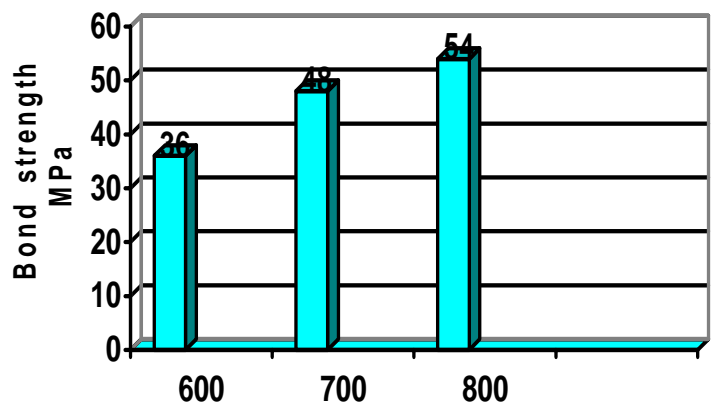

Electric carrent $\mathrm{A}$

Figure 3 - Bond strength of Ni22Cr10Al1Y layers Slika 3 - Čvrstoća spoja Ni22Cr10Al1Y slojeva 
The tensile testing showed that in all deposited coatings the mechanism of destruction took place at the interface between the substrate and the coating phase. Since the proportion of pores, nonmelted particles and oxides directly relates to the values of microhardness and bond strength of coatings, the measured values for the coating deposited with the highest amperage in the sample $C$ indicate that their number was minimal in this coating. These values are also confirmed by the analysis of the microstructure of coatings on a light microscope.

The microstructures of the Ni22Cr10Al1Y coating layers deposited with the current intensity of 600, 700 and 800 A are shown in Figs. 4, 5 and 6 . The qualitative analysis showed that defects such as discontinuity of the deposited layers on substrates, micro cracks and macro cracks and separation of the coating from the base (Fig. 4) are not present in the interface between the substrate and the deposited coating. In addition, there was no contamination due to a roughening agent. The structure of the inner layers of all coatings is of a lamellar type, with the basis of a solid solution of chromium and aluminum in nickel $-\mathrm{y}-\mathrm{Ni}+\mathrm{y}^{\prime}-\mathrm{Ni} 3 \mathrm{Al}$ phase. In the coating layers deposited with 600A, there were no nonmelted powder particles ranging from 53 microns to 106 microns (Fig. 4).

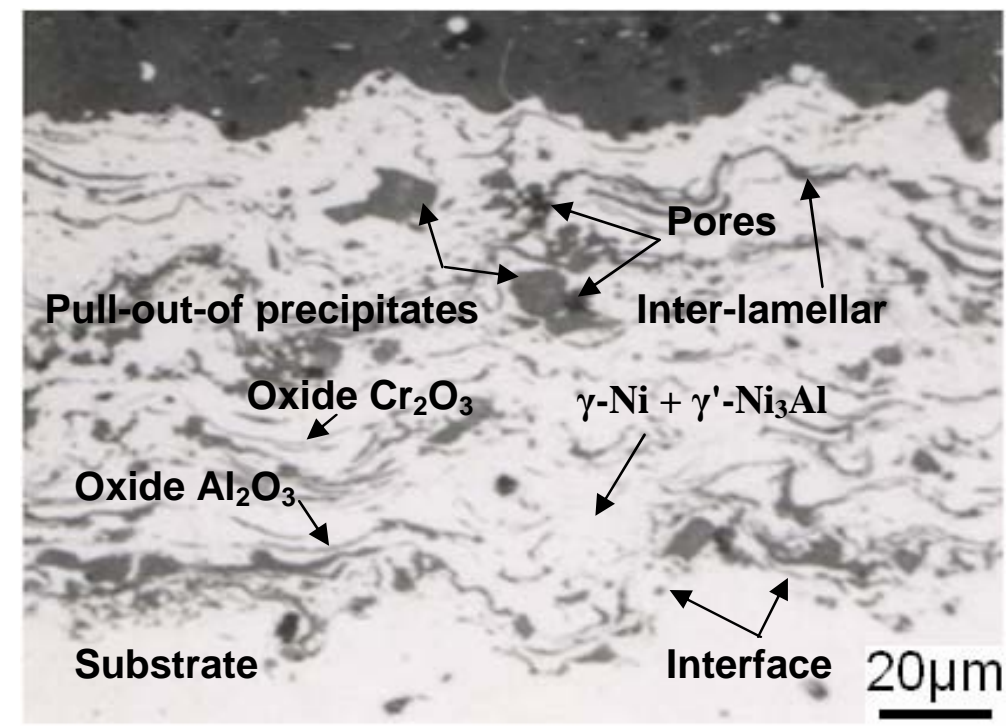

Figure 4 - Microstructure of the NI22Cr10Al1Y coating deposited with 600A on the sample A Slika 4 - Mikrostruktura NI22Cr10Al1Y prevlake deponovane sa 600A na uzorku A

In the structure, there are extracted precipitates of a spherical shape, which are seen as black as a result of the collision fields. Precipitates are a result of the collision of melted particles with the 
substrate. At the time of the collision, melted particles waste at the ends and remain as residue in the coating. Through the layers of coating, inter lamellar and spherical pores up to $5 \mu \mathrm{m}$ in size can be observed. The structure also contains the lamellae of the $\alpha-\mathrm{Al}_{2} \mathrm{O}_{3}$ and $\mathrm{Cr}_{2} \mathrm{O}_{3}$ oxides. In the deposition process, the incorporated molecules of oxygen $\mathrm{O}_{2}$ from the air are broken down into atoms in plasma at a temperature of $3227^{\circ} \mathrm{C}$ and they react with the atoms of $\mathrm{Al}$ and $\mathrm{Cr}$. Coarse oxides are also present in the structure. Coarse oxides and longer oxide lamellae are formed during collisions of liquid molten oxides with the substrate. These oxides are formed directly in the liquid state in plasma. Depending on the amount of the formed liquid oxide phase, its internal and kinetic energy, lamellae of coarse oxide of different sizes will be formed. In the coating layers, thin gray oxide films formed between the lamellae of the $\mathrm{Y}-\mathrm{Ni}$ base can be clearly observed, originating from the oxidation of $\mathrm{Al}$ and $\mathrm{Cr}$ in the process of solidification and cooling with the compressed air. The layers deposited with 600A have the highest proportion of pores, precipitates and coarse oxide lamellae. Through the layers of the coating, micro cracks and macro cracks cannot be observed. The coating layers deposited on the sample B with 700A do not contain non-melted powder particles (Fig. 5).

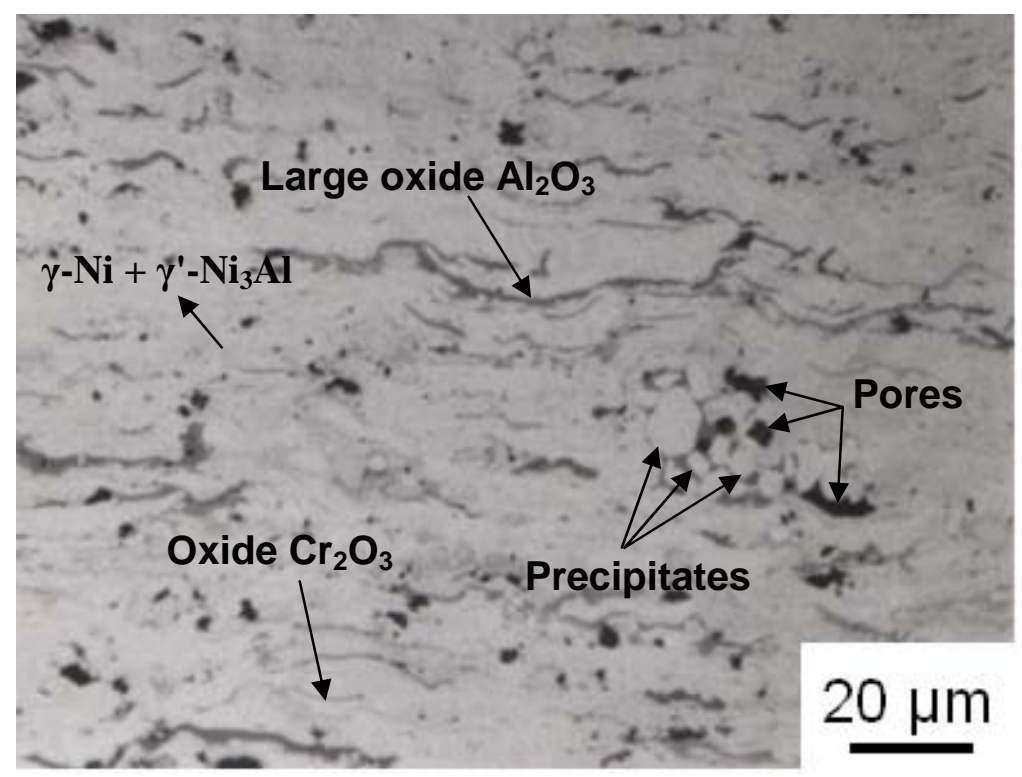

Figure 5 - NI22Cr10AI1Y coating microstructure deposited with700A on the sample $\mathrm{B}$ Slika 5 - Mikrostruktura NI22Cr10Al1Y prevlake deponovane sa 700A na uzorku B 
The structure contains spherical light gray precipitates of $5-10 \mu \mathrm{m}$ in size. Near precipitates, there are black pores resulting from precipitate formation. The share of pores is lower than that in the coating deposited on the sample $A$ with $600 \mathrm{~A}$. The structure also contains longitudinal lamellar $\mathrm{Al}_{2} \mathrm{O}_{3}$ oxide formed in the liquid state in plasma. Oxide plates are longer and thinner than in the layers deposited with 600A due to better smear on the surface where molten oxide particles are deposited. Between the longitudinal oxide lamellae, light gray base phase and solid solution of the $\mathrm{Y}-\mathrm{Ni}+\mathrm{Y}^{\prime}-\mathrm{Ni}_{3} \mathrm{Al}$ phase are clearly observed. Thin oxide films of $\alpha-\mathrm{Al}_{2} \mathrm{O}_{3}$ and $\mathrm{Cr}_{2} \mathrm{O}_{3}$ formed between the lamellae of the $\mathrm{Y}-\mathrm{Ni}$ base are clearly observed in the structure of the coating. The coating layers do not contain micro cracks and macro cracks.

Fig. 6 shows Ni22Cr10Al1Y layers with the best mechanical and structural characteristics deposited on the sample $C$ with the highest current intensity of $800 \mathrm{~A}$. The structure of the coating is lamellar. The coating base consists of a solid solution $\mathrm{y}-\mathrm{Ni}$ which includes a fine $\mathrm{Y}^{\prime}-\mathrm{Ni}_{3} \mathrm{Al}$ phase. Dark inter lamellar and spherical pores with a low level of share in the coating are clearly observed through NiCrAlY layers. base Thin films of $\alpha-\mathrm{Al}_{2} \mathrm{O}_{3}$ and $\mathrm{Cr}_{2} \mathrm{O}_{3}$ oxides, evenly distributed in the coating, are clearly observed between the base lamellae. Due to higher rates of melted particles and their shorter stay within the stream of plasma, neither coarse oxides are visible in coating layers nor non-melted particles, precipitates, micro cracks and macro cracks through the layers of coatings.

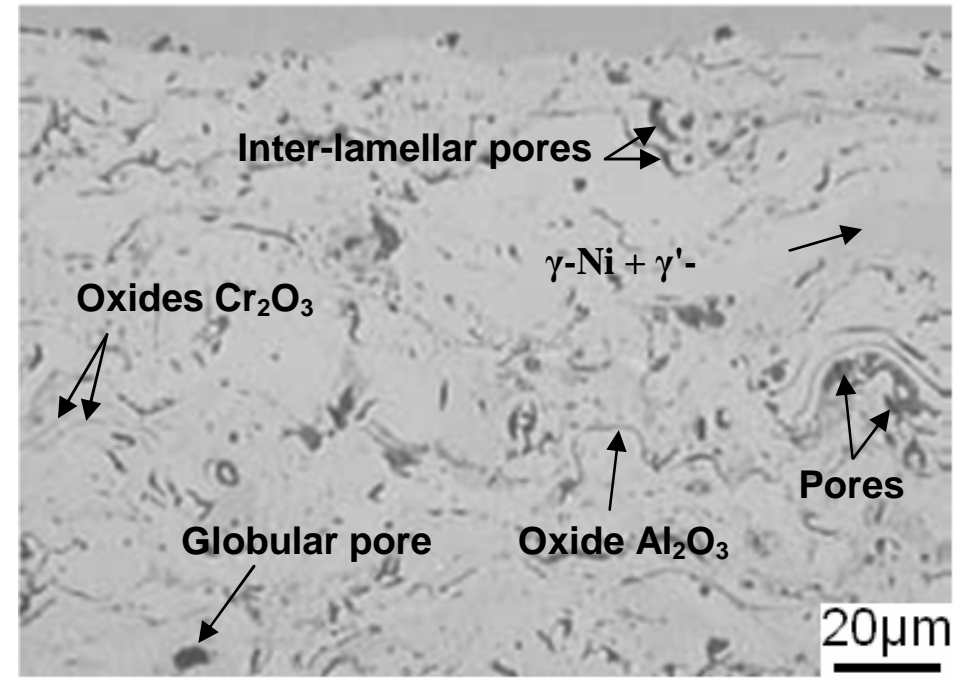

Figure 6 - NI22Cr10AI1Y coating microstructure deposited with 800A on the sample C Slika 6 - Mikrostruktura NI22Cr10Al1Y prevlake deponovane sa 800A na uzorku C 
Fig. 7 shows the SEM microstructure of the coating on the sample $C$ tested to oxidation in a furnace for heat treatment without a protective atmosphere at $1100^{\circ} \mathrm{C}$ for one hour. In the Ni22Cr10Al1Y coating microstructure, there are obvious changes compared with the microstructure of the coating in the deposited state. Based upon the EDS measurements and the results shown in Fig. 8 and Table 2, some phases in the marked coating regions can be expected. In the Ni22Cr10Al1Y alloy, there has been an expected stechiometric change of the elements $\mathrm{Al}, \mathrm{Cr}$ and $\mathrm{Ni}$ caused by diffusion at high temperature.

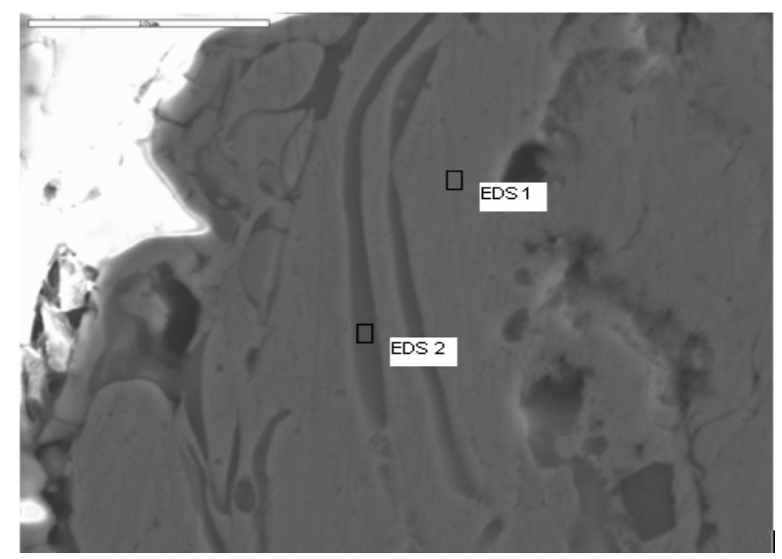

Figure 7 - SEM microphotography of Ni22Cr10Al1Y coating : sample (C) $1100^{\circ} \mathrm{C} / 1$ hour Slika 7 - SEM mikrofotografija Ni22Cr10Al1Y prevlake : uzorak (C) $1100^{\circ} \mathrm{C} / 1$ sat

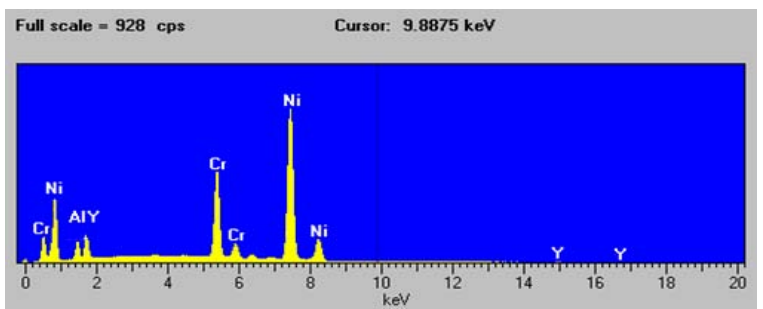

(a)

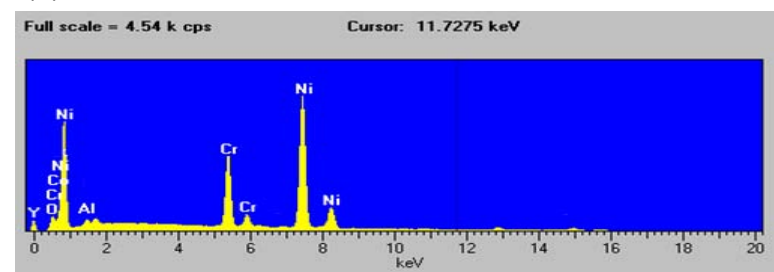

(b)

Figure 8 - EDS analysis of the Ni22Cr10Al1Y coating in Fig. 7(a) EDS 1 (b) EDS 2 Slika 8 - EDS analiza prevlake Ni22Cr10AI1Y na slici 7 (a) EDS 1(b) EDS 2 
The results of the SEM/EDS analysis indicated in Fig. 7 (in\%): $1100^{\circ} \mathrm{C} / 1$ hour

Table 2

Tabela 2

Rezultati SEM / EDS analize naznačene na slici 7 (u\%): $1100^{\circ} \mathrm{C} / 1$ sat

\begin{tabular}{|c|c|c|}
\hline$\%$ & EDS 1 & EDS 2 \\
\hline $\mathrm{O}$ & - & 25.80 \\
\hline $\mathrm{Al}$ & 2.16 & 14.67 \\
\hline $\mathrm{Cr}$ & 10.8 & 24.25 \\
\hline $\mathrm{Ni}$ & 86.12 & 34.95 \\
\hline $\mathrm{Y}$ & 0.92 & 0.33 \\
\hline
\end{tabular}

The solid $\mathrm{y}$ - Ni solution is depleted with elements such as $\mathrm{Al}$ and $\mathrm{Cr}$ (EDS 1). Only a small amount of $\mathrm{Al}$ remains in the regions rich in $\mathrm{Ni}$ and $\mathrm{Cr}$ $[17,18,19,20]$. Some authors in the studies $[23,24]$ also show that there is diffusion and oxidation of $\mathrm{Ni}$ from the solid $\mathrm{y}-\mathrm{Ni}$ solution. Nickel oxidizes to $\mathrm{NiO}$ and reacts with the already existing oxides $\mathrm{Cr}_{2} \mathrm{O}_{3}$ which are thermodynamically unstable at $1100^{\circ} \mathrm{C}$. These oxides build a stable spinel phase $\mathrm{NiCr}_{2} \mathrm{O}_{4}$. In Fig. 7, the EDS 2 analysis confirms that layers of dark gray mixed oxides are formed in the coating. This gray area contains mixed oxides of $\mathrm{Al}_{2} \mathrm{O}_{3}$ type and spinels $(\mathrm{Ni}, \mathrm{Cr})_{2} \mathrm{O}_{4},(\mathrm{Cr}, \mathrm{Al})_{2} \mathrm{O}_{4}[21]$.

\section{Conclusion}

Three groups of samples of Ni22Cr10Al1Y coatings were deposited in the atmospheric conditions by the plasma spray procedure, using three different amperages of $800 \mathrm{~A}, 600 \mathrm{~A}$ and $700 \mathrm{~A}$ which correspond to plasma gun power supplies of $22 \mathrm{KW}, 28 \mathrm{KW}$ and $34 \mathrm{KW}$. Mechanical and structural characteristics of the deposited layers were tested and analysed as well as the effect of oxidation on the microstructure of the deposited layers with the best characteristics.

The increase in amperage resulted in higher microhardness values. The third group of samples deposited with the amperage of $800 \mathrm{~A}$ had the highest values of microhardness. The third group also had the highest values of the bond tensile strength, while the fracture occurred along the interface between the coating and the substrate. The tensile strength values of all three groups were higher than the minimum value required by the appropriate standard. Microhardness and tensile strength values were in correlation with their microstructures.

The structure of the deposited Ni22Cr10Al1Y coating layers is lamellar and consists of a solid solution of chromium and aluminum in nickel $\gamma-\mathrm{Ni}, \gamma^{\prime}$ $+\mathrm{Ni}_{3} \mathrm{Al}$ phase, oxides $\alpha-\mathrm{Al}_{2} \mathrm{O}_{3}$ and $\mathrm{Cr}_{2} \mathrm{O}_{3}$ and interlamellar micro-pores. 
In the microstructure of the Ni22Cr10Al1Y coating, after temperature treatment at $1100^{\circ} \mathrm{C}$ for one hour, there was a change in the microstructure compared to the coating in the deposited state. Due to diffusion and oxidation of the elements at $1100^{\circ} \mathrm{C}$, the structure of the primary solid solution $\gamma-\mathrm{Ni}$ is depleted of $\mathrm{Cr}$ and $\mathrm{Al}$. Because of the thermal instability of $\mathrm{NiO}$ and $\mathrm{Cr}_{2} \mathrm{O}_{3}$ oxides at $1100^{\circ} \mathrm{C}$, the structure of the coating contains $\mathrm{Al}_{2} \mathrm{O}_{3}$ oxides and mixed spinels $(\mathrm{Ni}, \mathrm{Cr})_{2} \mathrm{O}_{4},(\mathrm{Cr}, \mathrm{Al})_{2} \mathrm{O}_{4}$.

The application of the coating with the best structural and mechanical properties during the reparation of a part of an ASTAZOU III $B$ turbojet engine has significantly improved its efficiency and reliability.

\section{Literatura}

[1] Patterson, T., Leon, A., Jayaraj, B., Liu, J., Sohn, Y. H., Surf. Coat. Technol. 203, 437(2008).

[2] Nicoll, A. R., The Environment - High Temperature Oxidation and Hot Corrosion, Plasma Technik AG, 5610 Wohlen Swityerland.

[3] AMDRY 963 Ni22Cr10Al1Y powder, An Engineering guide to Coating Performance and Applications, SULZER METCO The Coatings Company.

[4] Badrour, L., Moya, E. G., Bernardini, J., Moya, F., Scr. Metall. 20(1986)1217. (2000).

[5] Nicholls, J. R.,"Design of Oxidation Resistant Coatings"JoM 52 (1), 28-35

[6] Nicholls, J. R. and Saunders, S. R. J., in High Temperature Materials for Power Engineering' (Eds. E. Bachelet et al), Kluwer Academic Publishers, Dordrecht, 1990), pp. 865-875.

[7] Malik, M., Morbioli and Huber, P., In 'High Temperature Alloys for Gas Turbines' Conf Proc. (ed. R. Brunetaud et. al.) 87-98, Dordrecht, D. Reidel Publishing Co (1982).

[8] Luthra, K. L. and LeBlanc, O. H., Mater, Sci.\& Eng. 88 (1987), 329.

[9] Mom, A. J. A., NLR Report MP 81003U, Amsterdam.1981.

[10] Novak, R. C., (1994), cited in reference17.

[11] Brossard, S., Munroe, P. R., Tran, A. T. T., Hyland, M. M., Study of the effects of surface chemistry on splat formation for plasma sprayed $\mathrm{NiCr}$ onto stainless steel substrates, Surface \& Coatings Technology SCT-15342, pp. 1-9, 2009.

[12] Brossard, S., Munroe, P. R., Tran, A. T. T., Hyland, M. M., Study of the microstructure of $\mathrm{NiCr}$ splats plasma sprayed on to stainless steel substrates by TEM, Surface \& Coatings Technology SCT-15341, pp. 1-8, 2009.

[13] Tran, A. T. T., Hyland, M. M., Qin, T., Withy, B., James, B. J., in: E. Lugscheider (Ed.), Thermal Spray 2008: Crossing Borders (Proceedings of International Thermal Spray Conference 2008). Pub. DVS - Verlag $\mathrm{GmbH}$, 40223 Dusseledorf, Germany, 2008, pp. 701.

[14] Chatterjee, U. K., Bose, S. K., and Roy. S. K., Environmental Degradation of Metals, Pub., Marcel Dekker, 270 Madison Avenue, New York (2001). 
[15] ASM Handbook, Volume 3, Alloy Phase Diagrams, ASM International, Metals Park, 1992.

[16] Mrdak, M., Uticaj brzine depozicije praha na mehaničke karakteristike i strukturu APS - NiCr/Al prevlake, Vojnotehnički glasnik/Military Technical Courier, Vol. 58, No. 4, , pp. 5 -16, Ministry of Defence of the Republic of Serbia, Belgrade 2010.

[17] Leea, D. B., High-temperature oxidation of NiCrAlY/ $\left(\mathrm{ZrO}_{2}-\mathrm{Y}_{2} \mathrm{O}_{3}\right)$ and $\mathrm{ZrO}_{2}-\mathrm{CeO}_{2}-\mathrm{Y}_{2} \mathrm{O}_{3}$ ) composite coatings, Changhee Leeb a Center for Advanced Plasma Surface Technology, Sungkyunkwan University, Suwon 440-746, South Korea, Division of Materials Science and Engineering, Hanyang University, Seoul $133-791$, South Korea Available online 21 September 2004, Surface \& Coatings Technology 193 (2005), pp. 239-242.

[18] Moussa, S. O. and Morsi, K., "High-Temperature Oxidation of Reactively Processed Nickel Aluminide Intermetallics", Journal of Alloys and Compounds, Vol. 426, No. 1-2, 2006, pp. 136-143.

[19] Lee, D., Santella, M. L., Anderson, I. M. and Pharr, G. M., "Thermal Aging Effects on the Microstructure and Short- Term Oxidation Behavior of a Cast Ni3Al Alloy,"Intermetallics, Vol. 13, No. 2, 2005, pp. 187-196.

[20] Choi, S. C., Cho, H. J. and Lee, D. B., "Effect of Cr, Co, and Ti Additions on the High-Temperature Oxidation Behavior of Ni3Al," Oxidation of Metals, Vol. 46, No.1-2, 1996, pp. 109-127.

[21] Liu, J., Jayaraj, B., Sohn, Y., University of Central Florida, Orlando, FL, "Microstructural Development of Thermal Barrier Coatings with Air Plasma Sprayed NiCoCrAlY Bond Coats "International Thermal Spray Conference \& Exposition, May 14-17, 2007, Beijing, China.

[22] "Turbojet engine-standard practices manuel", TURBOMECA.

[23] Weizhou, Li, Yueqiao, Li, Chao, Sun, Zhiliu, Hu, Tianquan, Liang, Wuquan, Lai, J. Alloys Compd. (2010), 506, 77 (2010).

[24] Yuan, F. H., Chen, Z. X., Huang, Z. W., Wang, Z.G., Zhu, S. J., Corros. Sci. 50, 1608, 2008.

ISTRAŽIVANJE SVOJSTAVA PLAZMA DEPONOVANIH SLOJEVA NIKAL- HROM-ALUMINIJUM-ITRIJUM PREVLAKE OTPORNE NA OKSIDACIJU I TOPLU KOROZIJU

OBLAST: hemijske tehnologije

VRSTA ČLANKA: originalni naučni članak

Sažetak:

Cilj ove studije bio je da se istraživanjem svojstava slojeva Ni22Cr10Al1Y dobiju optimalne strukturno-mehaničke karakteristike sa optimizacijom parametara deponovanja. Prah je deponovan atmosferskim plazma sprej (APS) postupkom sa jačinama električne struje 600,700 i 800A koje odgovaraju snazi napajanja plazma pištolja $22 \mathrm{KW}, 28 \mathrm{KW}$ i $34 \mathrm{KW}$. 
Procene slojeva prevlake Ni22Cr10Al1Y napravljene su na osnovu njihovih mikrotvrdoća, zatezne čvrstoće i mikrostrukture. Najbolje performanse su pokazali slojevi deponovani sa 800A i snagom napajanja plazma pištolja od $34 \mathrm{KW}$. Prevlaka sa najboljim karakteristikama testirana je na oksidaciju u peći za termičku obradu bez zaštitne atmosfere na $1100^{\circ} \mathrm{C}$ u trajanju od jednog sata. Morfologija čestica praha Ni22Cr10Al1Y i EDS analiza najboljih slojeva ispitana je na SEM-u (skening elektronskom mikroskopu). Mikrostruktura slojeva deponovanih prevlaka ispitana je na svetlosnom mikroskopu. Mikrostrukturna analiza deponovanih slojevima urađena je u skladu sa standardom TURBOMECA. Procena mehaničkih karakteristika slojeva urađena je ispitivanjem mikrotvrdoće metodom $\mathrm{HV}_{0.3} \mathrm{i}$ čvrstoće spoja ispitivanjem na zatezanje. Istraživanja su pokazala da snaga napajanja plazma pištolja bitno utiče na mehaničke osobine i mikrostrukture prevlaka koje su od presudnog uticaja na zaštitu delova izloženih visokotemperaturnoj oksidaciji i vreloj koroziji.

Uvod

Za zaštitu delova turbomlaznih motora od uticaja visokih temperatura, posebno od uticaja oksidacije $i$ vrele korozije, najčešće se primenjuju legure tipa MeCrAlY ( $\mathrm{Me}=\mathrm{Ni}$, Co i / ili Fe). Izbor i sastav materijala u velikoj meri je uslovljen optimizacijom odnosa fizičko-hemijskih osobina primenjenog materijala i supstrata, radnom temperaturom i načinom depozicije [1]. Legurama tipa NiCrAlY najčešće se dodaje itrijum u određenim količinama. Dodatak itrijuma ima suštinski značaj, jer bitno povećava adheziju oksida $\mathrm{Al}_{2} \mathrm{O}_{3}$ i $\mathrm{Cr}_{2} \mathrm{O}_{3}$ koji se formiraju u prevlaci sa osnovom prevlake $i$ tako sprečava pucanje $i$ odvajanje zaštitnog površinskog oksidnog sloja pri dejstvu toplotnog zamora [2]. Produžetak životnog veka zaštitnih slojeva na oksidaciju doveo je do razvoja prevlake Ni22Cr10Al1Y. Prevlaka se obično koristi $u$ avio industriji, na delovima kao što su lopatice $i$ drugi delovi gasne turbine, kao zaštita na toplu koroziju ili visokotemperaturnu oksidaciju do $1100^{\circ} \mathrm{C}$ [3]. Višegodišnje iskustvo i modeliranje ponašanja slojeva prevlaka, zajedno sa poboljšanjem tehnika deponovanja, dovela je do razvoja višekomponentnih prevlaka. Veoma bitan uticaj na kvalitet slojeva prevlake imaju parametri deponovanja. Za atmosfersku plazma sprej (APS) tehniku jedan od bitnih parametara je jačina struje koja utiče na: stepen jonizacije plazma gasa, na temperaturu plazme, temperaturu čestica praha koja se tope, na njihovu brzinu u toku deponovanja i razlivanje na supstrat. Osnovni hemijski element prevlake NiCrAlY namenjene za zaštitu od visokotemperaturne oksidacije $i$ vrele korozije treba da bude kompatibilan sa materijalom supstrata da bi se smanjila interdifuzija i hemijska aktivnost Al. Aluminijum je element koji u prevlakama štiti legure $\mathrm{Ni}$ od oksidacije do $1200^{\circ} \mathrm{C}$ formiranjem faza $\alpha-\mathrm{Al}_{2} \mathrm{O}_{3}, \mathrm{~V}^{\prime}-\mathrm{Ni}_{3} \mathrm{Al}$ i $\mathrm{Y}^{-}$ $\mathrm{Ni} / \mathrm{V}^{\prime}-\mathrm{Ni}_{3} \mathrm{Al}$ u osnovi legure $\mathrm{Ni}$. Faza $\alpha-\mathrm{Al}_{2} \mathrm{O}_{3}$ u osnovi $\mathrm{NiCrAlY}$ legure ima uticaj na poboljšanje oksidacione otpornosti. Oksidna faza $\alpha-\mathrm{Al}_{2} \mathrm{O}_{3}$ ometa difuziju $\mathrm{Ni} i \mathrm{Cr}$ iz unutrašnjih slojeva na površinu prevlake i na taj način usporava rast oksida $\mathrm{Cr}_{2} \mathrm{O}_{3}$ i $\mathrm{NiCr}_{2} \mathrm{O}_{4}$, koji se pripisuje ni- 
skom koeficijentu difuzije $\mathrm{Ni}$ i $\mathrm{Cr}$ duž granice zrna $\alpha-\mathrm{Al}_{2} \mathrm{O}_{3}$. Oksid $\alpha-\mathrm{Al}_{2} \mathrm{O}_{3}$ koji se formira u prevlaci je termodinamički stabilna faza $\mathrm{i}$ veoma sporo raste $u$ odnosu na druge tipove oksida. Pored prisutnih oksida Ni, Cr i Al, prisutna je i spinel faza $\mathrm{NiCr}_{2} \mathrm{O}_{4}$ koja takođe povećava otpornost na oksidaciju [11,12,13]. Generalno, prah MeNiCrY se dobro deponuje atmosferskim plazma sprej sistemom i prevlaka ima dobru čvrstoću spoja sa osnovnim materijalom. U strukturi prevlake u plazma sprej deponovanom stanju su prisutne dve veoma važne faze na bazi $\mathrm{Ni}(\mathrm{Y}-\mathrm{Ni}$, $\gamma^{\prime}-\mathrm{Ni}_{3} \mathrm{Al}$ ) i oksidna faza $\alpha$-Al2O3. Unutrašnja struktura prevlake je heterogena mešavina osnove metala sa ne rastopljenim česticama praha, precipitatima, mikroporama i oksidima nikla $\mathrm{NiO}$ i hroma $\mathrm{Cr}_{2} \mathrm{O}_{3}$ i NiCr2O3. Izlaganjem prevlake na visokim temperaturama dolazi do oksidacije Al koji formira oksid tipa $\alpha-\mathrm{Al}_{2} \mathrm{O}_{3}$.Ovaj oksid se izdvaja na površini prevlake zbog velike brzine difuzije Al. Samo mala količina Al ostaje u regionima bogatim $(\mathrm{Ni}, \mathrm{Cr})$ [17]. Na temperaturi od $1200^{\circ} \mathrm{C}$ oksid $\mathrm{NiO}$ u prevlaci se destabilizuje i reaguje sa $\mathrm{Cr}_{2} \mathrm{O}_{3}$ formirajući tanak sloj spinel faze $\mathrm{NiCr}_{2} \mathrm{O}_{4}$ koja je termodinamički stabilnija od oksida $\mathrm{NiO} i \mathrm{Cr}_{2} \mathrm{O}_{3}[18,19,20]$. Na temperaturi $1200^{\circ} \mathrm{C}$ u prevlaci NiCrAlY se formiraju slojevi mešovitih oksida sive boje. U ovoj sivoj oblasti su mešoviti oksidi tipa $\mathrm{Al}_{2} \mathrm{O}_{3}, \mathrm{Cr}_{2} \mathrm{O}_{3}$ i spinel ( Ni,Cr) ${ }_{2} \mathrm{O}_{4},(\mathrm{Cr}, \mathrm{Al}){ }_{2} \mathrm{O}_{4}$ [21]. U ovom radu predstavljeni su rezultati eksperimentalnih istraživanja uticaja atmosferskih plazma sprej parametara na mehanička svojstva i mikrostrukturu slojeva Ni22Cr10Al1Y prevlake. Glavni cilj je bio da se homologuje prevlaka i primeni na sprovodnom vencu gasne turbine turbo-mlaznog motora ASTAZOU III B. Urađene su tri grupe uzoraka sa tri različite snage napajanja plazma pištolja 22 KW, 28 KW i 34 KW, sa vrednostima jačine struje od 600,700 i 800 A. Prevlaka sa najboljim karakteristikama je testirana na oksidaciju u peći za termičku obradu bez zaštitne atmosfere na $1100^{\circ} \mathrm{C}$ u trajanju od 1 sata. Analizirane su i proučavane mikrostrukture i mehaničke karakteristika slojeva prevlaka da bi se na osnovu rezultata odabrala prevlaka najboljeg kvaliteta $i$ homologovali plazma sprej parametri.

Materijali i eksperimentalni detalji

Materijal supstrata je od nerđajućeg čelika X15Cr13 (EN 1.4024). Materijal je korišćen u termički neobrađenom stanju. Za proizvodnju prevlake otporne na visokotemperaturnu oksidaciju i vrelu koroziju koristio se prah firme Sulzer Metco sa oznakom AMDRY 962. Ovaj prah NiCrAlY je legura nikla sa 20tež\% Cr, 10 tež\% Al i 1 tež\%Y sa rasponom granulacije čestica praha od $53 \mu \mathrm{m}$ do $106 \mu \mathrm{m}$. U eksperimentu za depoziciju praha je korišćen atmosferski plazma sprej(APS). $U$ tu svrhu korišćen je MINI GUN plazma sprej pištolj firme Plasmadyne, koji se sastoji od : katode tip K 1083-129 A , anode tip A 2084 -F45 i gas injektora tip GI 2084 B -103. Kao gas korišćen je argon u kombinaciji sa helijumom i električna struja od 600,700 I 800A sa snagom napajanja plazma pištolja od $22 \mathrm{KW}, 28 \mathrm{KW}$ i $34 \mathrm{KW}$. 
Mehaničke i mikrostrukturne karakterizacije dobijenih prevlaka izvršene su prema standardu TURBOMECA [22]. Za merenje tvrdoće $i$ metalografska ispitivanja korišćeni su pravougaoni uzorci $70 \times 20 \times 1,5 \mathrm{~mm}$, dok su za zateznu čvrstoću korišćeni cilindrični uzorci Ø25x50 mm. Mikrostrukturna analiza prevlaka urađena je na svetlosnom mikroskopu, dok je morfologija praha i EDS analiza prevlake testirane na oksidaciju na $1100^{\circ} \mathrm{C}$ u trajanju od 1 sata urađena na SEM-u (skening elektronskom mikroskopu).

Merenja mikrotvrdoća izvršena su korišćenjem Vikers dijamant piramide indenter i 300 grama opterećenje (HV 0.3$)$. Merenje je obavljeno u pravcu duž lamela, u sredini i na krajevima uzorka. Na tri mesta sprovedena su tri očitavanja a dobijeni rezultati su usrednjeni.

Testovi zatezne čvrstoće vršeni su na sobnoj temperaturi na hidrauličnoj opremi brzinom od $10 \mathrm{~mm} / \mathrm{min}$, za sva ispitivanja. Čvrstoća je izračunata tako što se opterećenje kidanja deli sa površinom poprečnog preseka uzorka. Geometrija uzoraka je u skladu sa ASTM C633 standardom. Korišćeni su u paru dva uzoraka, od kojih je prevlaka deponovana samo na jednom od njih. Uzorci su zalepljeni lepkom $i$ čuvani pod pritiskom jedni prema drugom u peći na temperaturi od $180^{\circ} \mathrm{C}$ za 2 sata. Za svaki grupu uzoraka urađene su po tri epruvete, a dobijeni rezultati su usrednjeni.

\section{Rezultati i diskusija}

Za sve deponovane prevlake dobijene su vrednosti mikrotvrdoće iznad zahtevane vrednosti od $200 \mathrm{HV}_{0.3}$ [22]. Vrednosti električne struje koje su u direktnoj vezi sa snagom napajanja plazma pištolja uticale su bitno na vrednosti mikrotvrdoće i čvrstoće spoja deponovanih slojeva. Najviše vrednosti mikrotvrdoće $342 H V_{0.3}$ pokazali su slojevi deponovani na uzorku (C) sa najvećom jačinom struje od 800A. Veća jačina struje je uticala na veće topljenje i povećanje brzine istopljenih čestica praha. To je rezultiralo boljim i gušćim pakovanjem jednih čestica na druge praćeno malim udelom između lamelarnih pora i oksida. Najnižu vrednost mikrotvrdoće od $220 \mathrm{HV}_{0.3}$ imali su slojevi deponovani na uzorku (A) koji su deponovani sa jačinom struje od 600A. Slojevi sa najvećom mikrotvroćom imali su najmanji udeo pora. Ove vrednosti su potvrđene za sve tri grupe uzoraka analizom mikrostrukture prevlaka na svetlosnom mikroskopu. Vrednosti mikrotvrdoća su bile u skladu sa udelima pora u deponovanim slojevima prevlaka. Vrednosti mikrotvrdoće deponovanih slojeva su u očekivanim granicama. Poređenjem vrednosti zatezne čvrstoće spoja dobijenih prevlaka, ustanovljeno je da su se za sve tri grupe uzoraka dobile vrednosti više od $35 \mathrm{MPa}$, koliko propisuje odgovarajući standard [22]. Niža vrednost zatezne čvrstoće spoja $36 \mathrm{MPa}$ prevlake na uzorku $(A)$ je posledica manje jačine struje, što je uticalo na manji stepen stapanja čestica praha u odnosu na druga dva sloja deponovana sa većom jačinom struje. Najveću vrednost čvrstoće spoja $54 \mathrm{MPa}$ su pokazali slojevi, koji su deponovani sa 
najvećom jačinom struje na uzorku(C). Ti slojevi su imali najmanji udeo pora i grubih oksida. Ispitivanja zatezne čvrstoće spoja je pokazalo da se za sve deponovane prevlake mehanizam razaranja odvijao na interfejsu između substrata i prevlake. Pošto je udeo pora, neistopljenih čestica i oksida u direktnoj vezi sa vrednostima mikrotvrdoće i čvrstoće spoja prevlaka, to izmerene vrednosti za prevlaku deponovanu sa najvećom jačinom struje na uzorku (C) ukazuje da je njihov udeo minimalan u ovoj prevlaci. Ove vrednosti su takođe potvrđene analizom mikrostrukture prevlaka na svetlosnom mikroskopu. Mikrostrukture slojeva Ni22Cr10Al1Y prevlaka deponovanih sa jačinom struje od 600,700 i 800 A prikazane su na slikama 4, 5 i 6. Kvalitativna analiza je pokazala da na interfejsu između supstrata i deponovanih prevlaka nisu prisutni defekti kao što je diskontinuitet deponovanih slojeva na supstratima, mikropukotine, makropukotine i odvajanje prevlaka od osnove (sl. 4). Takođe, nije uočena kontaminacija sredstvom za hrapavljenje. Struktura unutrašnjih slojeva svih prevlaka je lamelarna, čiju osnovu čini čvrst rastvor hroma $i$ aluminijuma u niklu $\gamma-\mathrm{Ni}+\gamma^{\prime}-\mathrm{Ni}_{3} \mathrm{Al}$ faza. $U$ slojevima prevlake deponovane sa 600A u strukturi se ne uočavaju neistopljene čestice praha čiji je raspon od $53 \mu \mathrm{m}$ do $106 \mu \mathrm{m}$ (sl. 4). U strukturi su prisutna mesta sa izvađenim precipitatima sfernog oblika koja se vide kao crna polja. Preciputati su posledica sudara istopljenih čestica praha sa supstratom. U trenutku sudara istopljena čestica se na krajevima odlama i ostaje kao talog u prevlaci. Kroz slojeve prevlake uočavaju se interlamelarne i sferne pore veličine do $5 \mu \mathrm{m}$. U strukturisu takođe prisutne lamele oksida $\alpha-\mathrm{Al}_{2} \mathrm{O}_{3}$ i Cr2O3. $U$ procesu depozicije inkorporirani molekuli kiseonika $\mathrm{O}_{2}$ iz vazduha na temperaturi od $3227^{\circ} \mathrm{C}$ u plazmi se razlažu na atome i reaguju sa atomima $\mathrm{Al} \mathrm{i} \mathrm{Cr}$. U strukturi su prisutni i grubi oksidi. Grubi oksidi i duže oksidne lamele formiraju se za vreme sudara tečnog rastopa oksida sa supstratom. Ovi oksidi se direktno formiraju u tečnom stanju u plazmi. Zavisno od količine formirane tečne oksidne faze, njene unutrašnje $i$ kinetičke energije formiraće se grube oksidne lamele različite veličine. U slojevima prevlake takođe se jasno uočavaju tanki oksidni filmovi sive boje formirani između lamela $y$ - Ni osnove koji potiču od oksidacije Al i Cr u procesu očvršćavanja $i$ hlađenja komprimovanim vazduhom. Slojevi deponovani sa 600A imaju najveći udeo pora, precipitata i grubih oksidnih lamela. Kroz slojeve prevlake ne uočavaju se mikroprskotine $i$ makroprskotine. U slojevima prevlake deponovane na uzorku B sa $700 \mathrm{~A}$ nisu prisutne neistopljene čestice praha (sl. 5). U strukturi su prisutni precipitati sfernog oblika veličine od 5 do $10 \mu \mathrm{m}$ svetlosive boje. $U$ blizini precipitata vide se pore crne boje koje su posledica formiranja precipitata. Udeo pora je manji u odnosu na prevlaku deponovanu sa 600A na uzorku A. U strukturi su prisutne podužne oksidne lamele $\mathrm{I}_{2} \mathrm{O}_{3}$ formirane u tečnom stanju u plazmi. Oksidne lamele su duže $i$ tanje $u$ odnosu na slojeve deponovane sa 600A zbog boljeg razlivanja 
na podlozi na kojoj se deponuju istopljene čestice. Između podužnih lamela oksida jasno se uočava svetlosiva faza osnove, čvrst rastvor $\mathrm{V}-\mathrm{Ni}+\mathrm{V}^{\prime}-\mathrm{Ni}_{3} \mathrm{Al}$ faza. U strukturi prevlake jasno se uočavaju tanki oksidni filmovi $\alpha-\mathrm{Al}_{2} \mathrm{O}_{3}$ i $\mathrm{Cr}_{2} \mathrm{O}_{3}$ formirani između lamela $\mathrm{V}-\mathrm{Ni}$ osnove. $U$ slojevima prevlake nisu prisutne mikroprskotine i makroprskotine.

$\mathrm{Na}$ slici 6. prikazani su Ni22Cr10Al1Y slojevi sa najboljim mehaničkim i strukturnim karakteristikama koji su deponovani na uzorku C sa najvećom jačinom struje od 800 A. Struktura prevlake je lamelarna. Osnova prevlake se sastoji od čvrstog rastvora $y-N i$ u kojem se nalazi fina faza $\mathrm{Y}^{\prime}-\mathrm{Ni}_{3} \mathrm{Al}$. Kroz NiCrAlY slojeve jasno se uočavaju tamne interlamelarne $i$ sferne pore sa niskim udelom u prevlaci. Između lamela osnove jasno se uočavaju tanki filmovi oksida $\alpha-\mathrm{Al}_{2} \mathrm{O}_{3} i$ $\mathrm{Cr}_{2} \mathrm{O}_{3}$ koji su ravnomerno distribuirani u prevlaci. Zbog veće brzine istopljenih čestica i kraćeg zadržava čestica u mlaz plazme u slojevima prevlake se ne uočavaju grubi oksidi. Kroz slojeve prevlake takođe se ne uočavaju nestopljene čestice, precipitat, mikroprskotine i makroprskotine. Na slici 7. je prikazana (SEM) mikrostruktura prevlake na uzorku (C) testirane na oksidaciju u peći za termičku obradu bez zaštitne atmosfere na $1100^{\circ} \mathrm{C}$ u trajanju od 1 sata.

$U$ mikrostrukturi Ni22Cr1OAl1Y prevlake postoje očigledne promene $u$ poređenju sa mikrostrukturom prevlake $u$ deponovanom stanju. Na osnovu obavljenih EDS merenja i rezultata prikazanih na slici 8. i tabeli 2. neke faze u okviru obeleženih regiona prevlake mogu se očekivati. U Ni22Cr10Al1Y leguri je došlo do očekivane stehiometrijske promene elemenata Al, Cr i Ni uzrokovane difuzijom na visokoj temperaturi. Čvrsti rastvor $y$ - Ni je osiromašio sa elementima kao što su Al i Cr (EDS 1). Samo mala količina Al ostaje u regionima bogatim (Ni,Cr) [17]. Neki autori u studijama [23,24] pokazuju da, takođe, dolazi do difundacije $i$ oksidacije Ni iz čvrstog rastvora $y-N i$. Nikal oksiduje do $\mathrm{NiO}$ i reaguje sa već postojećim oksidima $\mathrm{Cr}_{2} \mathrm{O}_{3}$ koji su termodinamički nestabilni na $1100^{\circ} \mathrm{C}$. Ovi oksidi grade stabilnu spinel fazu NiCr204. Na slici 7 (EDS 2) analiza potvrđuje da su u prevlaci formirali slojevi mešovitih oksida tamnosive boje. U ovoj sivoj oblasti prisutni su mešoviti oksidi tipa $\mathrm{Al}_{2} \mathrm{O}_{3}$, i spineli $(\mathrm{Ni}, \mathrm{Cr})_{2} \mathrm{O}_{4},(\mathrm{Cr}, \mathrm{Al}){ }_{2} \mathrm{O}_{4}$ [21].

\section{Zaključak}

Plazma sprej postupkom u atmosferskim uslovima deponovane su tri grupe uzoraka prevlake Ni22Cr10Al1Y, primenom tri različite jačine električne struje 600,700 i 800 A koje odgovaraju snazi napajanja plazma pištolja $22 \mathrm{KW}, 28 \mathrm{KW}$ i $34 \mathrm{KW}$. Istraživane su i analizirane mehaničko-strukturne karakteristike deponovanih slojeva $i$ uticaj oksidacije na mikrostrukturu slojeva deponovanih sa najboljim karakteristikama.

Povećanjem jačine struje dobijale su se sve veće vrednosti mikrotvrdoće prevlaka. Treća grupa uzoraka deponovana sa jačinom struje od 800 A imala je najveće vrednosti mikrotvrdoće. Treća grupa uzoraka takođe je imala najveće vrednosti zatezne čvrstoće spoja, a lom je išao na interfejsu između prevlake i površine na koju je prevlaka 
deponovana. Vrednosti zatezne čvrstoće spoja za sve tri grupe uzoraka bile su više od minimalne vrednosti propisane standardom za odgovarajuću namenu. Vrednosti mikrotvrdoće i zatezne čvrstoće spoja bile su u korelaciji sa njihovim mikrostrukturama.

Struktura deponovanih slojeva prevlake Ni22Cr10Al1Y je lamelarna i sastoji se od čvrstog rastvora hroma $i$ aluminijuma u niklu $\gamma-\mathrm{Ni}$, $\gamma^{\prime}+\mathrm{Ni}_{3} \mathrm{Al}$ faza , oksida $\alpha-\mathrm{Al}_{2} \mathrm{O}_{3} i \mathrm{Cr}_{2} \mathrm{O}_{3}$ i među lamelarnih mikropora.

U mikrostrukturi Ni22Cr10Al1Y prevlake posle temperaturnog tretmana na $1100{ }^{\circ} \mathrm{C}$ u trajanju od 1 sata došlo je do promene mikrostrukture u poređenju sa prevlakom u deponovanom stanju. Zbog difuzije $i$ oksidacije elemenata na $1100^{\circ} \mathrm{C}$, struktura primarnog čvrstog rastvora $\gamma-\mathrm{Ni}$ je osiromašila na $\mathrm{Cr}$ i Al. Zbog termičke nestabilnosti oksida NiO i $\mathrm{Cr}_{2} \mathrm{O}_{3}$ na $1100^{\circ} \mathrm{C}$, u strukturi prevlake su prisutni oksidi tipa $\mathrm{Al}_{2} \mathrm{O}_{3}$, i mešoviti spineli $(\mathrm{Ni}, \mathrm{Cr})_{2} \mathrm{O}_{4},(\mathrm{Cr}, \mathrm{Al})_{2} \mathrm{O}_{4}$. Primenom prevlake sa najboljim strukturno-mehaničkim karakteristika, pri reparaciji dela turbomlaznog motora ASTAZOU IIIB znatno se poboljšala njegova efikasnost i pouzdanost rada.

Ključne reči: atmosferski plazma sprej (APS), mikrostruktura, interfejs, mikrotvrdoća, čvrstoća spoja, oksidacija, vrela korozija.

Datum prijema članka: 17. 11. 2011.

Datum dostavljanja ispravki rukopisa: 25. 12. 2011.

Datum konačnog prihvatanja članka za objavljivanje: 27. 12. 2011. 